\title{
SOCIO-ECONOMIC FACTORS BEHIND THE PREVALENCE OF CHILD LABOR IN AGRICULTURE SECTOR OF DISTRICT LASBELA, BALOCHISTAN, PAKISTAN
}

\author{
Mobeen Ahmed \\ Lecturer \\ Department of Sociology \\ Lasbela University of Agriculture, Water and Marine Sciences \\ Uthal, Baluchistan - Pakistan \\ ahmedmubeen153@gmail.com \\ Sanaullah \\ Lecturer \\ Department of Sociology \\ Lasbela University of Agriculture, Water and Marine Sciences \\ Uthal, Baluchistan - Pakistan \\ sanavellah3377@gmail.com \\ Shakir Adam \\ Lecturer \\ Department of Humanities \\ Lesbela University of Agriculture, Water and Marine Science \\ Uthal, Baluchistan - Pakistan \\ Shakiradam1988@gmail.com
}

\begin{abstract}
Child labor is one of the major and serious problems across the globe, with the number of children are escalating each year. There are thousands of children working in agriculture sector as child labor. The prevalence of agriculture child labor is extensive in less developed countries. Agriculture occupies a significant place in the economic prosperity of Pakistan, as well as it is one of the main sectors where people are associated for earing and livelihood. The objective of this study is to determine the socio-economic factors behind the child labor in agriculture sector of district Lasbela, Balochistan. Lasbela is considered a major agriculture zone in Balochistan and there are large number of children
\end{abstract}




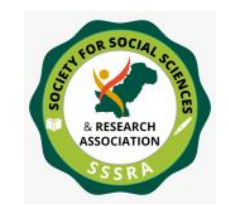

Pak. Journal of Int'L Affairs, Vol 4, Issue 2 (2021) Socio-Economic Factors Behind the Prevalence ...

who are working as child labor in this area. The main cause which leads to children toward labor activities is poverty and low household income. A child working as a laborer in the fields of agriculture is to assist their family's income. In the present research, 50 children who were working as laborer were selected through the purposive sampling technique. They were interviewed through semi-structured interview which consist of number of questions. Mostly working children were illiterate and dropouts from schools. Majority of the working children face some issues related to their physical and mental health. Thus, this study discovered that mostly working children come to agriculture sector due to low household income and inherited poverty in district of Lasbela, Balochistan.

Keywords: Agriculture, child labor, poverty, low-income, socio-economic, Lasbela, Balochistan

\section{Introduction}

Children are the building blocks and assets for the progress and future of any society and a nation. Child development is related to the development and growth of any society and nation. Every country has the responsibility to manage the children in a safe, sound, caring and educated environment. Children with the age of 5 or so have only responsibility to engage in education and playing. Parents are accountable to send their children to educational institutions (school), and give them supportive, cheerful, and educated ground. (Bernard van Leer Foundation 2004). Children can improve, develop, grow, modernize, and build future societies. But unfortunately, child labor deluges children across the globe. The world is home to billion individuals aged 10-19 years. Regardless of its threat in different structures, the information shows variety in predominance of child labor over the globe and the factual figures about child labor are exceptionally disturbing. There are an expected 186 million child workers around the world. (Srivastava, K. 2011).

There is a need for creating distinction between child labor and child work. If the health, personal development such as schooling of the children is not affected, this sort of work can't be considered as form of child labor. Assisting the family business or doing work during school vacations are another example of child work, which can't be termed as "child work". However, any work that has the possibility to affect the childhood, their "dignity, self-respect and also harmful to their physical, psychological, moral and mental development and it interferes with their education" is called child labor. (ILO, 2001) Child labor can be defined as, "the employment of boys and girls when they are too 


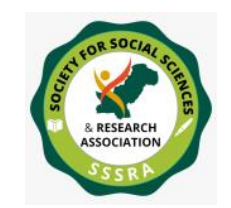

Pak. Journal of Int'L Affairs, Vol 4, Issue 2 (2021) Socio-Economic Factors Behind the Prevalence ...

young to hire for work or when they are employed at jobs unsuitable or unsafe for the children of their age or under conditions hostile to their health". (USDL, 1957)

This phenomenon is responsible for keeping them engaged or busy in other professional activities rather than education and playing. These children are paid less amount as compared to a grown worker. Meanwhile, his/her compensation are also received by parents, guardians or by their master. Innocent little child who should be at school or at playgrounds are on the path of earning for their own and their families living. (Pasha, et al, 2001)

McConnell argued and considered $19^{\text {th }}$ and $20^{\text {th }}$ centuries as more developed in capitalistic worldwide. The evil of child labor was widespread in $19^{\text {th }}$ century. Farming as the oldest traditional occupation is significant for survival, and, later many societies and nations had adopted agriculture as their main occupation. The $20^{\text {th }}$ century, however, witnessed a rapid transformation and development in the growth of farming and agriculture sector. The meet the rising demand of laborers, migrant workers were hired along with women and children because of low wages. The large families were preferred because the labor was cheap in the families. (McConnell, 2012)

The idea of work and childhood activities went through a wide window of progress in the late eighteenth century and now the condition is that many of the country's child labor is no more acceptable. With the advancement of global scenario still there are cases and parts of world where child labor is present at large extent with high degree and is under severe practice and highly acknowledged by the societies particularly in the developing countries. (Fyfe, 1989)

\section{The Rationale behind Child Labor}

There are many reasons behind the child labor. The first and the far most reasons for child labor are poverty and lack of other alternatives for children from poor families such as education, unequal distribution of income. In less developed countries poor families rely on their children for contributing to household income. Children work to guarantee the survival of their family and themselves. Without getting equal pay, they are considered as a major contributor to family income in less developed countries. (ILO 2000)

Due to poverty and low income the poor families face many health problems and chronic disease. To overcome these problem children are sent to work by their family members. 


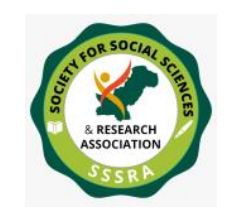

Pak. Journal of Int'L Affairs, Vol 4, Issue 2 (2021) Socio-Economic Factors Behind the Prevalence ...

Another important factor concerning child labor is the lack of awareness, indifference, and cultural traditions. In many societies child labor became customary. In some cultures, many sons are considered being proud. They think that children are the source of income. In some societies, child labor is perfectly acceptable and some culture also supportive for child labor. Because the understood it as an appreciated and meaningful activity which prepares the children for adult life (Marlenga et al. 2007).

Virtually poverty is the primary factor, which stimulates the children to work. Low family unit resources and income demands children commitment in the income of household. Children with low socio-economic background became victims most of the time. There is a strong economic pressure applied upon parents that compels them to make their children to work. These children have no substitute and decision but to give up to their parent's decision. The earning level and work status of their parents are extremely troubling particularly mother status of employment. (Hussain,M et al.2017)

As mentioned by Basu and Van (1998) that luxury proposition that when their family unable to meet their basic needs, the child still engages in labor activities. This proposal clearly explains the relation between poverty and child labor in labor economy. (Basu \& Van 1998)

Although, child labor is dubbed as outcome of poverty, the empirical evidence is weak. As a main source of informal economy in most developing nations, the children can be seen working in workshops and small factories, in dhabas and restaurant, as well as serve as domestic servants. It is commonly believed that as the household wealth increased, the children would be pulled out of the labor activities in favor of schooling. However, the deprivation of educational prospects would close the doors of possibilities and opportunities for children. Such schemes must be regarded as hazardous. Ahemd pointed out that unemployment, poverty, lack of education, overpopulation and health care are the major factors that forces to work in early ages of their childhood. (Ahmad, A. 2012)

The research conducted by Lindenmeyer, K. (2006) on child labors represents the case of child labor in these words, 'nine-year-old Abdel Moti exemplifies the reasons why many adolescents are reinstated as child labors. Abdel, who happened to be the youngest children work in a brick factory, begin working since he was 8 years old. He contributes alongside with his mother, who works as a housemaid, for running their household and for paying for the medicine of the ailing father. Abdel showed no regrets for leaving the school to work because of earing more money. Working in big farms, involving large number of resident and migrant young children was recognized a serious social issue. Agriculture is a one of the hazardous and risky work for the child. 


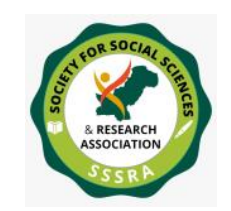

Pak. Journal of Int'L Affairs, Vol 4, Issue 2 (2021) Socio-Economic Factors Behind the Prevalence ...

\section{Child Labor in Agriculture Sector}

The child labor in agriculture is found in those societies that have high number of adult workers in agriculture. Agriculture field is the risky field for child because they work with heavy machinery, equipment, and tool such as knives, chainsaws, tall ladder, and tractor. During work child face heat stress, illness, thirsty, that causes serious health problem such as dehydration, heat illness result death occurs sometimes. Children also come to contact with pesticide through spraying the field, being blown by the wind, compared with adult child are in greater danger (Karr, C.2012).

According to Food and Agriculture Organization (FAO), about 70 percent of total account of child laborer work at agriculture sector which is nearly about 108 million boys and girls. (FAO, 2017) According to statistical information and monitoring program on child labor (2002), 18\% of children 5-17, are economically and financially active worldwide in different fields. A child labor termed as economically active if he or she done work on wages (cash or in kind), work in family farms in the production and processing of primary production and this agriculture production is for selling in markets or for their own consumption. Approximately, 211 million children who are working consist of $18 \%$ of the world's population of 5-17 years age. $60 \%$ of these children are from Asia and 52\% are male child, and other twenty three percent are from sub-Sarhan Africa. Most of the economically active children are prevailing in low-income countries, but SIMPCO estimated that $4 \%$ children are working in low-income countries while $2 \%$ children working in developed countries. (Edmonds, E. V., \& Pavcnik, N, 2005)

Agriculture plays a vital role for the progress and prosperity if any nation in the world. Pakistan is an agrarian country, and agriculture contributes greatly to the economic activities. It generates almost a quarter of Pakistan GDP. Since most people live in rural areas, almost two-third of the rural workforce is associated with this sector. As the lifeline of rural economy, the land is the main form of wealth. As a fact of matter, every community is directly or indirectly linked with agriculture, and their dependency is well established. (Spielman, D. J,et al 2016)

\section{Child labor in Pakistan}

As a great concern and "painful dilemma of our times", there are many factors for child labor. They are identified through various studies carried out all over the world. The nature and scale of these studies are limited to number of areas in Pakistan. Though, significant enough, they are unable to depict a complete picture of "child labor", "work conditions", and the causes behind the inception of child labor. (NRSP,n.d.) 


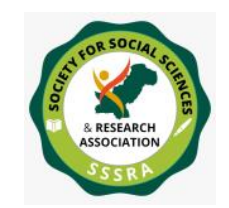

Pak. Journal of Int'L Affairs, Vol 4, Issue 2 (2021) Socio-Economic Factors Behind the Prevalence ...

In Pakistan, owing to low economic position of families, the children restore to work and economically support their families, leading to alarming rates of child laborers. (Shrestha, 2011) The situation is, however, bleak in rural areas of Pakistan due to widespread poverty. These poverty-stricken families depend upon their children to share the burden of the families, thus getting them involved in the child labor. The last nationwide survey conducted in 1996, with the technical support of ILO, showed that out of 40 million children, 3.3 million between the age 5 and 14 are economically active. The figure is "composed of approximately $73 \%$ boys and $27 \%$ girls." (ILO, 2006)

According to Zafar, Z. et al, (2016). Child labor is the growing hazard that impacted the development and economic growth of the country. Child labor is the developing condemnation on the globe especially in the developing countries and Pakistan is additionally the victim of this growing worldwide phenomenon because of multiple reasons behind which support intentionally or indirectly the dilemma of child labor. Child labor had different results that upset the social sitting of the society and its developing statistics alarms the public authority of Pakistan to take the most conceivable and suitable measures to overcome this curse. Further, there are certain socio-economic factors which are responsible for this problem which includes economic situation of parents, large extended family size, lack of free education and failure to implement laws regarding this issue.

As mentioned by (Ibupoto.M.h et al 2019), the Pakistan Bureau of Statistics and Labor Force survey 2012-2013 revealed that around 4.4\% percent of children between ages of 10-15 are tangled into Pakistan's active working force.

The survey highlights that "financial liability" as the far most factor for the parents and guardian to ask their children to work. Helping in household activities and adding into household incomes are other important reasons which are anticipated from the children. (Ashfaq, A., et al, 2017).

The death and illness of a family member is most important reason behind the practice of child labor. Poverty remains the primary factor behind child labor in Pakistan. On the other hand, lack is income opportunities is another great impediment for illiteracy, which also forced the children to indulge in child labor. Moreover, it seems that the government officials in Pakistan assumed the child labor problem is moved beyond all proportions and there is not much to panic about this issue. Multiple socio-economic factors, such as poverty, uneven distribution of wealth and economic opportunities, obsolete customs, ever rising unemployment, population growth make child labor is not an isolated 


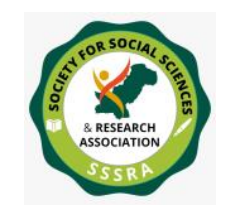

Pak. Journal of Int'L Affairs, Vol 4, Issue 2 (2021) Socio-Economic Factors Behind the Prevalence ...

problem. However, the government should bring the legislation into effect to solve this issue. (Moon 2013)

Research conducted on the sociological aspect of child labor in Pakistan used 250 respondents from the city of Karachi between age of 4-and 18-years age. The research recognizes that in all walks of life, child labor occurs. Many of the children come from poor classes. Some kids still work in the upper and lower middle class, but they typically work in the business which is owned by their family. The research showed that children do not drop out of school for work, but children also work out of school. On the supply side of child labor one of main factor is the low life expectancy of parents. Parents want to enjoy their planned short lives to the fullest Parents often feel pleased and proud of getting jobs and services from their children. By making their children work they abuse their parental authority. As well as research indicate that 80 percent of children perceive their lives to be bettered rather than children who are not working. According to them it is the work which provide them integrity, trust, and sense of worth for them. (Sabeeha, 1980)

\section{The Profile of District Lasbela, Balochistan}

District Lasbela is notably known for its unique landscape and geography occupies an important place in the region. Having situated in Kalat division, the entire region has famous for its agricultural production. The total population of district Lasbela is 574, 292 , out of which 295,048 are living in Rural area while 279,244 are living in urban areas. (Census, 2017).

District Lasbela headquarter is Uthal town, while there are nine tehsils which includes Bela, Hub, Uthal, Somiani, Lairi, Lakhra, Dureji Kannraj and Gaddani. Lasbela district is the $7^{\text {th }}$ largest in Balochisatn area wise with 15,153 sq. (Development profile of Lasbela District, 2015)

\section{Significance of the Study}

The basic rational of current research is to elaborate the child labor in agriculture sector of District Lasbela, Balochistan. As we can understand child labor is a much serious social and cultural problem, which is growing day by day in developing countries, like Pakistan generally and Balochistan in particular. A major objective of current research is to provide awareness regarding child labor involved in agriculture sector and identify the problems faced by of child laborer in Lasbela district. Moreover, this research highlights the social and economic condition of children and their families, and the behavioral 


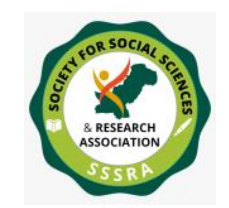

Pak. Journal of Int'L Affairs, Vol 4, Issue 2 (2021) Socio-Economic Factors Behind the Prevalence ...

attitude of the owner of the farms toward child labors. This study also clarified the conditions due to which children are compelled to work in agriculture sector as child laborer. The agriculture working conditions ware hazardous and perilous that further made the situation harsher, for affected children. The study also focused to describe the circumstances that occurred at a given time and place, including the abuse of children in the agricultural sector, such as physical, psychological, social, moral, mental, sexual exploitation. The study also explained these phenomena because most children lacked schooling due to poverty, lack of interest in education, and the teacher's harsh attitude.

This research is indicated the root cause of socio-economic factors behind the child labor in district Lasbela. However, different non-governmental organizations are already work on this issue for a long time but still some gaps need to be filled with the help of this study. Family members especially parents come to know the drawback of this issue and not to send their children at work for low wages. But rather to send them for education for their bright future

\section{Objectives:}

1. To identify the social condition of child labor in agriculture sector of District Lasbela, Balochistan.

2. To find the economic condition of child labor in agriculture sector of District Lasbela, Balochistan

\section{METHODS AND MATERIALS: Sample:}

The population of this research is consisting of 50 children who were working as child labor in agriculture fields of Lasbela district of Balochistan. The selection criteria of these 50 respondents were purely based upon their age specification and nature of their work. The present study used method of collecting primary data through purposive sampling method.

\section{Instruments:}

The data for this research was collected with the support of interview of schedule method which was comprised of 31 questions.

\section{Statistical Analysis:}

For interpreting the data statistically, Statistical Package for Social Sciences (SPSS) was used. Present study has utilized descriptive and explanatory research methods.

\section{Results:}


Pak. Journal of Int'L Affairs, Vol 4, Issue 2 (2021) Socio-Economic Factors Behind the Prevalence ...

\section{Percentage distribution regarding the question of Age of respondents}

\begin{tabular}{|l|l|l|l|l|}
\hline & Frequency & Percent & Valid Percent & $\begin{array}{l}\text { Cumulative } \\
\text { Percent }\end{array}$ \\
\hline 10 years and below & 17 & 34.0 & 34.0 & 34.0 \\
11 to14 years & 20 & 40.0 & 40.0 & 74.0 \\
15 to above & 13 & 26.0 & 26.0 & 100.0 \\
& & & & 0 \\
Total & 50 & 100.0 & 100.0 & \\
\hline
\end{tabular}

In this research total of 50 samples has taken. The above frequency table is showing that from 50 of total respondents 20 with the percentage of $40.0 \%$ were in the age bracket of 11 to 14 . Further 17 respondents with the percentage of $34 \%$ were 10 year and below by age. Moreover, remaining which were 13 with the percentage of $26.0 \%$ were 15 and above in the age bracket. Hence, this survey indicates that majority of the respondents are those working as a laborer in agriculture sector were 11 to 14 in their age bracket.

2. Percentage distribution regarding the question of Household Monthly Income

\begin{tabular}{|l|l|l|l|l|}
\hline & Frequency & Percent & Valid Percent & $\begin{array}{l}\text { Cumulative } \\
\text { Percent }\end{array}$ \\
\hline less than 10000 & 5 & 10.0 & 10.0 & 10.0 \\
less than 20000 & 35 & 70.0 & 70.0 & 80.0 \\
less than 30000 & 10 & 20.0 & 20.0 & 100.0 \\
Total & 50 & 100.0 & 100.0 & \\
\hline
\end{tabular}

Above table highlights the monthly income of the respondents. Whereas respondents with the percentage of $70 \%$ having less than 20000 as their household monthly income. While respondents with the percentage of $20 \%$ having less than 30000 monthly incomes of 
their family. However, respondents with the percentage of $10 \%$ are those whose monthly income is than 30000 .

\section{Percentage distribution regarding the question of Reason to work at Agriculture} sector

\begin{tabular}{|l|l|l|l|l|}
\hline & Frequency & Percent & Valid Percent & $\begin{array}{l}\text { Cumulativ } \\
\text { e Percent }\end{array}$ \\
\hline $\begin{array}{l}\text { family compelled me to } \\
\text { work }\end{array}$ & 5 & 10.0 & 10.0 & 10.0 \\
$\begin{array}{l}\text { own choice } \\
\text { lack of interest in } \\
\text { education } \\
\text { poverty } \\
\text { Total }\end{array}$ & 39 & 8.0 & 8.0 & 18.0 \\
\hline
\end{tabular}

Above mention table highlights the reason behind the working at agriculture as a child labor. Majority of the respondents with the percentage of $78 \%$ consider poverty as a major reason which force them to work as a labor while respondents with percentage of $10 \%$ believe the reason behind of their work as labor is their family pressure. Further, remaining of the respondents with percentage of $8 \%$ work by their own choice, however, few of them consider lack of interest in education is the reason behind to work in agriculture s with $2 \%$. Hence, poverty is one of the major reasons to work at agriculture. 
Pak. Journal of Int'L Affairs, Vol 4, Issue 2 (2021) Socio-Economic Factors Behind the Prevalence ...

4. Percentage distribution regarding the question of, where do you contribute your income?

\begin{tabular}{|ll|l|l|l|l|}
\hline & & Frequency & Percent & Valid Percent & Cumulative Percent \\
\hline \multirow{4}{*}{ Valid } & family & 48 & 96.0 & 96.0 & 96.0 \\
& Self & 1 & 2.0 & 2.0 & 98.0 \\
& friend & 1 & 2.0 & 2.0 & 100.0 \\
& Total & 50 & 100.0 & 100.0 & \\
\hline
\end{tabular}

As mentioned in the above table no.4 respondents were asked about the question of "where do they contribute their income "most of respondents answered that their income provide support mainly their families. Out of 50 respondents $48 \%$ clicked on option of family. $1 \%$ marked on self while other $1 \%$ marked on the option of friends.

\section{Percentage distribution regarding the question of, are you satisfied what you do for} yourself?

\begin{tabular}{|ll|l|l|l|l|}
\hline & & Frequency & Percent & Valid Percent & Cumulative Percent \\
\hline \multirow{4}{*}{ Valid } & Yes & 45 & 90.0 & 90.0 & 90.0 \\
& No & 5 & 10.0 & 10.0 & 100.0 \\
& Total & 50 & 100.0 & 100.0 & \\
\hline
\end{tabular}

As mentioned in the above table no. 5, respondents were asked about the question of whether they are satisfied what they do for their selves, most of the respondent marked the option of yes to show their agreeableness with the question. Out of 50 respondents $45 \%$ respondents selected the option of YES, while only $5 \%$ respondents indicated that they are not satisfied what they are doing to their selves.

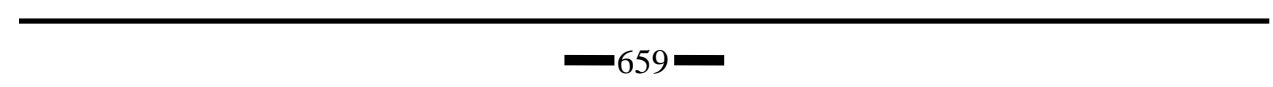




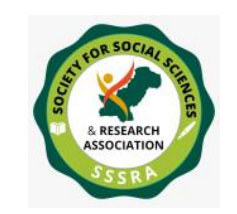

Pak. Journal of Int'L Affairs, Vol 4, Issue 2 (2021) Socio-Economic Factors Behind the Prevalence ...

\section{Percentage distribution regarding the question of, if you stop working what will happen?}

\begin{tabular}{|l|l|l|l|l|}
\hline & $\begin{array}{l}\text { Frequenc } \\
\mathrm{y}\end{array}$ & Percent & $\begin{array}{l}\text { Valid } \\
\text { Percent }\end{array}$ & Cumulative Percent \\
\hline $\begin{array}{l}\text { Household living } \\
\text { standard decline }\end{array}$ & 21 & 42.0 & 42.0 & 42.0 \\
$\begin{array}{l}\text { Household cannot } \\
\text { afford to live } \\
\text { Other }\end{array}$ & 28 & 56.0 & 56.0 & 98.0 \\
Total & 50 & 2.0 & 2.0 & 100.0 \\
\hline
\end{tabular}

As mentioned in above table no.6 respondents were asked about the question of what will happen if they decide to stop working as a child labor, most of respondents highlighted that they cannot afford to live in if they stop working. Out of 50 respondents 28 mentioned that they cannot afford to live without any job or working as a child labor while, 21 respondents mentioned that their families living slandered decline if they stop working and on respondents mentioned the reason for working as child labor for his own wish.

There are number of important assumptions that can be drawn from the current research by analyzing the data. Most crucially poverty has remained the most significant factor to push any individual or family to send their children at work. Same is the case with district of Lasbela, Balochistan. When respondents were asked about, what would happen if they stopped working most of respondents answer that they couldn't live their lives without working. Such indications clearly highlighted that poverty is the major cause that compel the children to start working as child laborer at a very young age.

Another major understanding was in regard of level of awareness among the children, most of children considered it very much normal to work as child laborer in agricultural fields in a very young age, while questions like weather they were satisfied as child labor or were they satisfied what they were doing with their selves', most of respondents mentioned that they were alright with their lives as child laborer, such responses clearly indicated that awareness is a very much important factor in regard of protecting any child from becoming a child labor or another word at least to make realize the children to think about the importance of life their lives while working in such harsh working condition

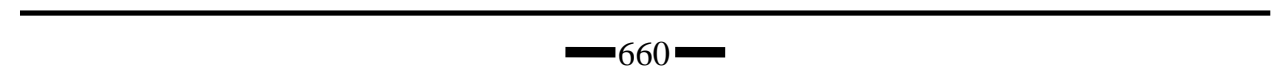




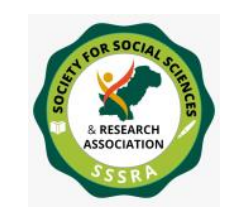

Pak. Journal of Int'L Affairs, Vol 4, Issue 2 (2021) Socio-Economic Factors Behind the Prevalence ...

,which mostly make them vulnerable in hands of their masters of senior coworkers. Most of children were very much strange about the words such as "satisfaction" like satisfaction with their job, their salary, working environment or life as whole, just because lack of awareness about their lives while working as child laborer.

\section{Conclusion}

Child labor is an issue of global concern, and it has many dimensions that influences the lives of people who are affected by child labor. Pakistan is a country where agriculture sector has a significant role to play in country's economy. Agriculture is one of the major sectors that contribute greatly to the problem of child labor in Pakistan. Lasbela district is an agriculture zone and most of laborers in this district are working in this sector of agriculture economy and child laborer weather boys or girls are major sources of labor in agriculture farms of district Lasbela.

\section{Recommendations}

- Government should start poverty reduction programs in ruler areas of Balochistan to eradicate or minimize the poverty in Lasbela district of Balochistan.

- Awareness programs and camping should launch by NGOs working in the district as well as civil society of district Lasbela.

- Government should provide rules, regulations, and instructions to farm masters, child labor and coworker in case of any injury and harm is caused by master, coworkers or any other third actor to any child working in agricultural fields.

- Government should take immediate actions in case of physical or emotional harm is caused by master of field or coworkers.

- Government should establish a child protection or child welfare section at local government level in Lasbela Balochistan to provide protection to those children who are vulnerable for any help.

- A system of proper check in balance should be establish by all farms owners, NGOs, or local government of Lasbela district to protect the social, physical, emotional, and economic wellbeing of those children who are working in fields of Lasbela district.

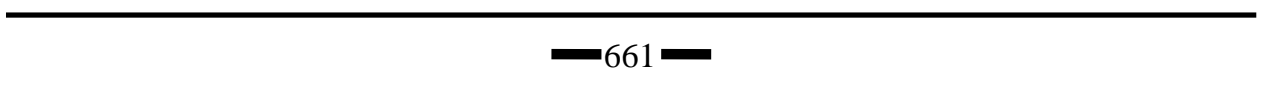


Pak. Journal of Int'L Affairs, Vol 4, Issue 2 (2021) Socio-Economic Factors Behind the Prevalence ...

\section{References}

Ahmad, A. (2012). Poverty, Education and Child Labour in Aligarh City India. Studies on Home and Community Science, 6(3), 165-172.

Ashfaq, A., Ali, R., Habiba, U., \&Ashfaq, M. (2017). Child labour in Pakistan: consequences on children's health. International Journal of Human Rights and Constitutional Studies, 5(1), 82-90.

Basu, K., \& Van, P. H. (1998). The economics of child labor. American economic review, 412-427.

Bernard Van Leer Foundation. (2004). Submission to the United Nations Committee on the Right of the Child.

Child labour in Agriculture. (2017) fao.org/childlabouragriculture

Edmonds, E. V., \&Pavcnik, N. (2005). Child labor in the global economy. Journal of Economic Perspectives, 19(1), 199-220.

Fund, P.P.A (2015) Situation Analysis \& baseline surveys for poverty reduction through rural development in KpK, FATA\& Balochistan

Fyfe, A. (1989). Child labour. Polity Press.

Hussain, M., \& Saud, A. (2017). Socio-Economic determinants of working children: evidence from Capital Territory of Islamabad, Pakistan. Pakistan Administrative Review, 1(2), 145-158.

Ibupoto, M. H., Mirjat, A. J., Dahar, S. H., \&Mahar, S. A. (2019). Child Labor in Agricultural Sector Hyderabad Sindh, Pakistan. Arts and Social Sciences Journal, 10, 1.

International Labor Organization. (2000). "Child Labor Causes." Journal of Child Laboring 4(2):3-4

International Labor Organization. (2001). "Child Labor Micro level”. Journal of Child Laboring 1(3): 2 
Pak. Journal of Int'L Affairs, Vol 4, Issue 2 (2021) Socio-Economic Factors Behind the Prevalence ...

Karr, C. (2012). Children's environmental health in agricultural settings. Journal of agromedicine, 17(2), 127-139.

Lindenmeyer, K. (2006). An historical perspective on child labor in the United States. Employee Responsibilities and Rights Journal, 18(2), 133-142.

Marlenga, B., Berg, R. L., Linneman, J. G., Brison, R. J., \& Pickett, W. (2007). Changing the child labor laws for agriculture: impact on injury. American journal of public health, 97(2), 276-282.

McConnell, E. D. (2012). House poor in Los Angeles: Examining patterns of housinginduced poverty by race, nativity, and legal status. Housing Policy Debate, 22(4), 605-631.

Moon, Banki. (2013). "Convention for Save Children”. Break the Silence to end violence against children 4(1): 3-6

NRSP.n.d.Child Labor in Cotton Industry A Rapid Assessment in District Lasbela Balochistan, Pakistan. National Rural Support Programme - Social \& Human Protection Programme

Pakistan Bureau of Statistics. ( 2017) Government of Pakistan, Census

Pasha, G. R., Iqbal, M., \& Farooq, S. K. (2001). Facts and Factors about the destiny of working and escaped children in Punjab (Pakistan). Pakistan Economic and Social Review, 1-24.

Sabeeha, Khan M. (1980). "Child labor in Multan City". Financial background of Child Laborers 5(2): 11-16.

Spielman,David j.Sohail j.Malik, Paul Dorosh \& Nuzhat Ahmed.(2016). Agriculture and Rural Economy of Pakistan university of Pennsylvania press Philadelphia.

Srivastava, K. (2011). Child labour issues and challenges. Industrial psychiatry journal, 20(1), 1.

United States Department of Labor. (1957). "Causes and Consequences of Child Labor”. 
Pak. Journal of Int'L Affairs, Vol 4, Issue 2 (2021) Socio-Economic Factors Behind the Prevalence ...

Zafar, Z., Sarwar, I., \&Haider, S. I. (2016). Socio-Economic and Political Causes of Child Labor: The Case of Pakistan. Global Political Review, 1(1), 32-43. 